\title{
Field Survey Considering Distribution of Fire Location Part 1 Survey Summary and Results
}

\author{
Yoshifumi Ohmiya $^{1}$, Kazunori Harada ${ }^{2}$, Jun Kitahori ${ }^{1}$, Norichika Kakae ${ }^{2}$ \\ and Ken Matsuyama ${ }^{1}$ \\ ${ }^{1}$ Tokyo University of Science \\ ${ }^{2}$ Kyoto University
}

Keywords : Flammable Materials, Field Survey, Local Fire, Heat Release, Exposed Surface Area

\section{INTRODUCTION}

The revised Building Standards Law in Japan (2002) introduced four performance verification protocols. One of the verifications for fire resistance performance was standardized by anticipating "uniformly distributed fire" and "localized fire" in terms of the design fire source. To date, much research has been conducted with respect to the flammable materials in order to incorporate this aspect into the fire safety design, but most of the research was mainly focused on the weight of the flammable material (e.g. fire load). The weight of the flammable material is a very important factor for calculating the burning duration under the assumption of a "uniformly-distributed fire". On the other hand, for the assumption used for the "localized fire" that does not induce flashover, it is necessary to understand the layout of the flammable materials in addition to the weight and to identify the fire source whose burning area is locally confinable in the design.

With this background, and taking into account a past survey on fire load, a survey was conducted in order to determine the actual layout condition of the flammable materials in a room that could be presumed in the context of a "localized fire" that does not induce flashover.

\section{SURVEY SUMMARY}

This survey was conducted with 6 different rooms, 5 of which were office buildings and 1 a school. Each room was categorized by the use of the room per building such as lobby, hallway and meeting room, and the layout conditions of the fire load were assessed. Figure 1 illustrates one of the examples used in the survey. 


\begin{tabular}{|c|c|c|c|c|c|c|c|}
\hline \multicolumn{4}{|c|}{ Sheet for flammable material survey } & \multicolumn{2}{|c|}{ Completed by: Ueta } & \multicolumn{2}{|c|}{ Date: 09/15/2004 } \\
\hline Survey No & $A \cdot 1$ & $\begin{array}{l}\text { Name of } \\
\text { building }\end{array}$ & & \multicolumn{2}{|c|}{ Building A } & Name of room & Lobby \\
\hline Use & School & Use of room & \multicolumn{3}{|c|}{ Lobby } & Activities & Magazine, Internet \\
\hline Structure & $\mathrm{RC}$ & Scale & 4 stories & Floor area & $182.3 \mathrm{~m}^{2}$ & Building area & Unknown $\mathrm{m}^{2}$ \\
\hline \multicolumn{8}{|c|}{ List of Flammable Materials } \\
\hline \multirow{2}{*}{ No. } & \multirow{2}{*}{ Name } & \multirow{2}{*}{ Type } & \multirow{2}{*}{ Qty } & \multirow{2}{*}{\multicolumn{2}{|c|}{$\begin{array}{c}\text { Size }(\mathrm{mm}) \\
\text { Width } \times \text { Depth } \times \text { Height }\end{array}$}} & \multicolumn{2}{|c|}{ Calorific value of the compartment } \\
\hline & & & & & & Parts Mate & ial Heat rate \\
\hline \multirow{2}{*}{$A \cdot 1 \cdot 1$} & \multirow{2}{*}{ Desk } & & \multirow{2}{*}{1} & \multirow{2}{*}{\multicolumn{2}{|c|}{$1000 * 900 * 600$}} & Top board & Particle board \\
\hline & & & & & & $1000 *$ & $900 * 20$ \\
\hline \multirow{3}{*}{ Type } & \multirow{2}{*}{\multicolumn{2}{|c|}{ Storage }} & \multirow{2}{*}{$\begin{array}{l}\text { Storage } \\
\text { coefficient }\end{array}$} & \multirow{2}{*}{ Mobility } & \multirow{2}{*}{ Remarks } & $11.7 \mathrm{~kg}$ & $135.7 \mathrm{MJ}$ \\
\hline & & & & & & \multirow[t]{2}{*}{ Other } & Steel \\
\hline & \multicolumn{2}{|c|}{ Yes $(\mathrm{L}, \mathrm{M}, \mathrm{S})$ or No } & & \multicolumn{2}{|l|}{ Movable } & & * $0.0 \mathrm{MJ}$ \\
\hline & & & & & Exposed wood & & \\
\hline & & & & & $1.88 \mathrm{~m}^{2}$ & $\begin{array}{c}* \\
0.0 \mathrm{~kg} \\
\end{array}$ & * $\quad 0.0 \mathrm{MJ}$ \\
\hline & & & & & Exposed plastic & * & \\
\hline & & & & $=$ & $0.00 \mathrm{~m}^{2}$ & $0.0 \mathrm{~kg}$ & $0.0 \mathrm{MJ}$ \\
\hline & & & & & Exposed contents & * & * \\
\hline & & & & & $000 \mathrm{~m}^{2}$ & $0.0 \mathrm{~kg}$ & $0.0 \mathrm{MJ}$ \\
\hline & & & & & $0.00 \mathrm{~m}^{-}$ & Cal. rate of $\mathrm{w}$ & $135.7 \mathrm{MJ}$ \\
\hline & & & & & Valid exposed area & Cal. rate of pla & $0.0 \mathrm{MJ}$ \\
\hline$y$ & & & & & $1.88 \mathrm{~m}^{2}$ & $\begin{array}{r}\text { Valid cal. value } \\
\text { furniture) }\end{array}$ & $135.7 \mathrm{MJ}$ \\
\hline
\end{tabular}

Figure 1 Example of the flammable material survey sheet

\section{DEFINITION OF SURVEY DATA (CALORIFIC VALUE AND EXPOSED AREA OFTHE FLAMMABLE MATERIAL)}

\subsection{Definition of calorific value of the flammable material}

\section{a) Calorific value}

In order to organize the data obtained from this survey, the flammable materials were described by calorific index rather than by the traditional weight index. Additionally, since most of the flammable materials are made of various materials such as wood and plastic, each material was measured per part in detail and each calorific value was calculated. 
i) Calorific value of wood

The characteristic value of several wooden materials (particle board, paper, etc.) was specified and calculated in order to determine the calorific value of the cellulosic materials.

ii) Calorific value of plastic

The characteristic value of several plastic materials (polyethylene, polyester, etc.) was specified and calculated in order to determine the calorific value of the cellulosic materials.

\section{b) Valid heat release rate}

The valid heat release rate is the heat release rate calculated by taking into account the condition of the flammable materials in terms of the shape and size of the flammable materials, materials of the storage furniture, and the condition of the stored flammable materials.

\subsection{Definition of the exposed surface area}

\section{a) Exposed surface area}

By taking into account that the heat release rate per exposed surface area $\left(1 \mathrm{~m}^{2}\right)$ varies depending on the exposed surface of the flammable materials of the furniture, the exposed surface of the plastic material was calculated as 3 times greater than that of the wooden material.

Additionally, based on the idea that if flammable materials were stored in furniture whose outer material is made of flammable material, then the burning would start from the outer material of the furniture, and therefore, the exposed surface area of the outer material was determined as the maximum burnable area, which is the exposed area of the furniture.

On the other hand, if the flammable materials were stored inside the furniture whose outer material is non-flammable material (e.g. a steel-made locker), no flammable material is exposed; however, it is possible that they may burn. Therefore, by assuming that the stored flammable materials would burn by a ventilation-induced fire, the exposed surface area of the stored materials was calculated as the apparent exposed surface area.

\section{b) Valid exposed surface area}

In the calculation of the exposed surface area, by considering the traditional survey method, the area facing other flammable materials or walls was subtracted from the exposed surface area of the flammable material.

Figure 2 illustrates the relation of exposed area of the flammable material, exposed area of the furniture's outer material, exposed surface area of the stored materials, and valid exposed surface area. 


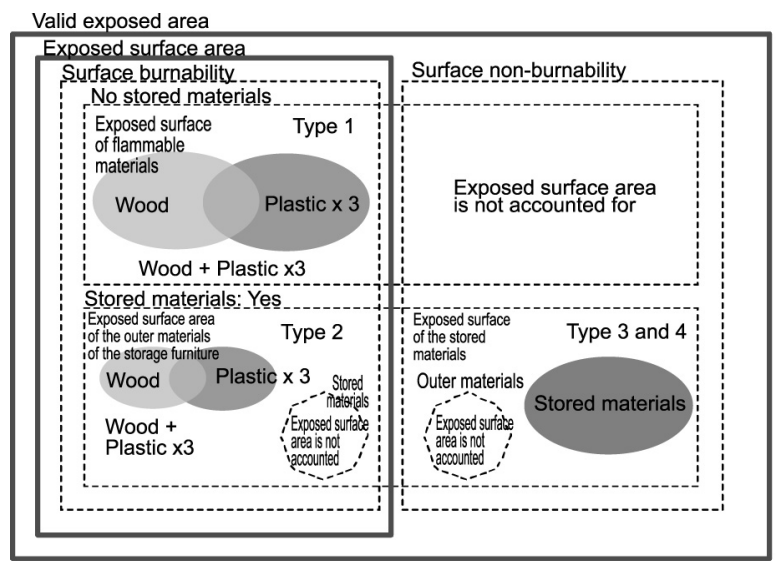

Figure 2 Definition of the exposed surface area

\section{SURVEY RESULTS}

Table 1 shows the survey data and illustrates the relation of calorific value of the flammable materials, exposed surface area and occupancy of the flammable materials with respect to the use of space and floor area. The occupancy of the flammable materials is defined as a percentage $\left(\mathrm{m}^{2} / \mathrm{m}^{2}\right)$ that is occupied by the flammable materials against the floor area in planar view. The mean occupancy values of the lounge, meeting room, hallway and lobby are approximately $0.26\left(\mathrm{~m}^{2} / \mathrm{m}^{2}\right), 0.335\left(\mathrm{~m}^{2} / \mathrm{m}^{2}\right), 0.032\left(\mathrm{~m}^{2} / \mathrm{m}^{2}\right)$ and $0.075\left(\mathrm{~m}^{2} / \mathrm{m}^{2}\right)$, respectively. The occupancy of the flammable materials is lower in the hallway and lobby than in the lounge and meeting room. In Part 2 of this report, a discussion will focus on "walkway areas" (e.g. hallway and lobby areas) and "room areas" (e.g. lounge and meeting room areas). 
Table 1 Survey results of the flammable materials

\begin{tabular}{|c|c|c|c|c|c|c|c|c|c|c|c|c|c|c|c|c|}
\hline $\begin{array}{l}\text { Bldg } \\
\text { name }\end{array}$ & Use & Category & Room use & Use category & $\begin{array}{c}\text { Floor area } \\
\left(\mathrm{m}^{2}\right)\end{array}$ & $\begin{array}{c}\text { No. of } \\
\text { furniture } \\
\text { items }\end{array}$ & $\begin{array}{c}\text { Total HRR } \\
\text { (M.J) }\end{array}$ & $\begin{array}{c}\text { Valid HHR } \\
\text { (M.J) }\end{array}$ & $\begin{array}{c}\text { Exposed } \\
\text { sufface } \\
\left(\mathrm{m}^{2}\right)\end{array}$ & $\begin{array}{c}\text { Valid } \\
\text { exposed } \\
\text { surface }\left(\mathrm{m}^{2}\right)^{2}\end{array}$ & $\begin{array}{l}\text { Flam. } \\
\text { material } \\
\text { conc. } \\
\left(\mathrm{MJ} / \mathrm{m}^{2}\right)\end{array}$ & $\begin{array}{c}\text { Valid flam. } \\
\text { material } \\
\text { conc. } \\
\left(\mathrm{MJ} / \mathrm{m}^{2}\right)\end{array}$ & $\begin{array}{c}\text { Surface } \\
\text { coefficient } \\
\left(m^{2} M_{j}\right)\end{array}$ & $\begin{array}{c}\text { Valid surface } \\
\text { coefficient } \\
\left(\mathrm{m}^{2} \mathrm{M}(\mathrm{d})\right.\end{array}$ & $\begin{array}{c}\text { Mean offset } \\
(\mathrm{mm})\end{array}$ & Occupancy \\
\hline \multirow{12}{*}{ Bldg $A$} & \multirow{12}{*}{ School } & \multirow{5}{*}{ Walkway } & Lobby & Lobby & 182 & 49 & 5007.8 & 5007.8 & 59.45 & 59.45 & 27.5 & 27.5 & 0.012 & 0.012 & 320 & 0.078 \\
\hline & & & 1F Hallway & Hallway & 233 & 87 & 16049 & 23273.4 & 33.29 & 104.2 & 68.9 & 99.9 & 0.002 & 0.004 & 39 & 0.061 \\
\hline & & & 2F Hallway & Hallway & 272 & 81 & 3678.8 & 4997.2 & 31.95 & 39.69 & 13.5 & 18.4 & 0.009 & 0.008 & 0 & 0.079 \\
\hline & & & 3P Hallway & Hallway & 272 & 54 & 4014.6 & 5351.84 & 28.35 & 30.25 & 14.8 & 19.7 & 0.007 & 0.007 & 0 & 0.044 \\
\hline & & & 4F Hallway & Hallway & 218 & 54 & 22680.3 & 23572.3 & 132.42 & 150.89 & 104.0 & 108.1 & 0.006 & 0.006 & 27 & 0.078 \\
\hline & & \multirow{6}{*}{ Room } & Media Center & Lounge & 75 & 19 & 2750.9 & 2750.9 & 30 & 30 & 36.7 & 36.7 & 0.011 & 0.011 & 1351 & 0.174 \\
\hline & & & Student Hall & Lounge & 113 & 37 & 4201 & 4201 & 66.6 & 66.6 & 37.2 & 37.2 & 0.016 & 0.016 & 878 & 0.125 \\
\hline & & & Computer Room & Computer Room & 90 & 127 & 1757101 & 17608.7 & 287.44 & 313.56 & 195.2 & 165.7 & 0.016 & 0.018 & 1534 & 0.356 \\
\hline & & & Refresh Room & Lounge & 27 & 25 & 2378.8 & 2845.8 & 37.72 & 41.34 & 88.1 & 105.4 & 0.016 & 0.015 & 578 & 0.393 \\
\hline & & & Library & Lounge & 66.5 & 50 & 7634.1 & 23915.1 & 188.35 & 294.3 & 114.8 & 359.6 & 0.024 & 0.012 & 1110 & 0.332 \\
\hline & & & Study Room & Lounge & 136 & 74 & 12205.6 & 12205.6 & 184.28 & 184.28 & 89.7 & 89.7 & 0.015 & 0.015 & 2027 & 0.283 \\
\hline & & Gym & Arena & Gym & 1540 & 12 & 23090.2 & 23090.2 & 264.52 & 264.52 & 15.0 & 15.0 & 0.011 & 0.011 & 618 & 0.004 \\
\hline \multirow{9}{*}{ Bldg B } & \multirow{9}{*}{ Office } & \multirow{4}{*}{ Wallkway } & Lobby & Lobby & 86.4 & 15 & 1675.2 & 1949.82 & 14.42 & 17.48 & 19.4 & 22.6 & 0.009 & 0.009 & 95 & 0.021 \\
\hline & & & 2F Hallway & Hallway & 28.8 & 1 & 7 & 7 & 0.79 & 0.70 & 0.2 & 0.2 & 0.113 & 0.113 & 0 & 0.003 \\
\hline & & & 4F Hallway & Hallway & 28.8 & 5 & 350.1 & 350.1 & 7.35 & 7.35 & 12.2 & 12.2 & 0.021 & 0.021 & 0 & 0.022 \\
\hline & & & ¿F Hallway & Hallway & 28.8 & 5 & 373 & 373 & 6.62 & 6.62 & 13.0 & 13.0 & 0.018 & 0.018 & 0 & 0.025 \\
\hline & & \multirow{4}{*}{ Room } & Meeting Room 1 & Meeting Room & 168 & 106 & 9595 & 39986.7 & 277.91 & 286.6 & 57.2 & 238.6 & 0.029 & 0.007 & 1090 & 0.227 \\
\hline & & & Meeting Room 8 & Meeting Room & 51.2 & 34 & 6621.1 & 6888.46 & 109.98 & 114.54 & 129.31 & 134.5 & 0.017 & 0.017 & 1309 & 0.333 \\
\hline & & & Meeting Room 11 & Meeting Room & 31.7 & 35 & 4015.9 & 19788.99 & 65.27 & 103.22 & 126.7 & 624.3 & 0.016 & 0.005 & 691 & 0.429 \\
\hline & & & Forum & Meeting Room & 65.6 & 57 & 16610.6 & 17127.89 & 206.92 & 227.98 & 253.2 & 261.1 & 0.012 & 0.013 & 480 & 0.326 \\
\hline & & Parking & Parking & Parking & 269 & 12 & 2680 & 2680 & 31.47 & 31.47 & 10.0 & 10.0 & 0.012 & 0.012 & 277 & 0.016 \\
\hline \multirow{3}{*}{ Bldg C } & \multirow{3}{*}{ Office } & & Lobby & Lobby & 427 & 57 & 26626.3 & 2662.3 & 396.12 & 396.12 & 62.4 & 62.4 & 0.015 & 0.015 & $1800^{\circ}$ & 0.056 \\
\hline & & Wallwivay & 1F Hallway & Hallway & 169 & 20 & 4085.3 & 4085.3 & 42.08 & 42,08 & 24.2 & 24.2 & 0.010 & 0.010 & 438 & 0.028 \\
\hline & & Room & Foyer & Lounge & 68.8 & 48 & 3786.2 & 3786.2 & 75.15 & 75.15 & 55.0 & 55.0 & 0.020 & 0.020 & 1236 & 0.121 \\
\hline \multirow{2}{*}{ Bldg D } & \multirow{2}{*}{ Office } & Wallkway & Lobby & Lobby & 420 & 210 & 20187.8 & 20187.8 & 352.15 & 352.15 & 48.0 & 48.0 & 0.017 & 0.017 & 995 & 0.032 \\
\hline & & Room & Forum & Lounge & 107 & 54 & 13991.35 & 16326.35 & 225.66 & 243.8 & 130.9 & 152.7 & 0.016 & 0.015 & 380 & 0.144 \\
\hline \multirow{10}{*}{ Bldg E } & \multirow{10}{*}{ Office } & \multirow{8}{*}{ Walkway } & Lobby & Lobby & 167 & 46 & 8741.29 & 8741.29 & 128.68 & 128.68 & 52.2 & 52.2 & 0.01 & 0.015 & 427 & 0.097 \\
\hline & & & 1F Hallway & Hallway & 70.3 & 7 & 1831.3 & 1831.3 & 14.8 & 14.8 & 26.0 & 26.0 & 0.008 & 0.008 & 0 & 0.002 \\
\hline & & & 2P Hallway & Hallway & 121 & 10 & 5612.9 & 5612.9 & 109.76 & 109.76 & 46.5 & 46.5 & 0.020 & 0.020 & 0 & 0.013 \\
\hline & & & 3F Hallway & Hallway & 107 & 27 & 7628.52 & 7765.26 & 117.18 & 124.2 & 71.3 & 72.6 & 0.015 & 0.016 & 23 & 0.070 \\
\hline & & & 4F Hallway & Hallway & 79 & 4 & 1588.2 & 1588.2 & 27.51 & 27.51 & 20.1 & 20.1 & 0.017 & 0.017 & 100 & 0.000 \\
\hline & & & ${ }_{5 \mathrm{~F}}$ Hallway & Hallway & 53.2 & 7 & 535.2 & 535.2 & 5.73 & 5.73 & 10.1 & 10.1 & 0.011 & 0.011 & 100 & 0.006 \\
\hline & & & 6P Hallway & Hallway & 50.6 & 8 & 465 & 465 & 44,03 & 11.03 & 9.2 & 9.2 & 0.024 & 0.024 & 50 & 0.028 \\
\hline & & & 7F Hallway & Hallway & 93.9 & 22 & 8648.6 & 8648.6 & 51.76 & 51.76 & 92.1 & 92.1 & 0.006 & 0.006 & 37 & 0.042 \\
\hline & & \multirow{2}{*}{ Room } & Service Room & Service Room & 6.72 & 7 & 1089.6 & 1665.42 & 9.58 & 45.68 & 162.1 & 247.8 & 0.009 & 0.027 & 0 & 0.261 \\
\hline & & & Lounge & Lounge & 85 & 57 & 5349 & 5974.96 & 194.31 & 198.14 & 62.9 & 70.3 & 0.036 & 0.033 & 715 & 0.235 \\
\hline \multirow{8}{*}{ Bldg $\mathrm{F}$} & \multirow{8}{*}{ Office } & & Lobby & Lobby & 114 & 2 & 95 & 95 & 3.28 & 3.28 & 0.8 & 0.8 & 0.035 & 0.035 & 145 & 0.000 \\
\hline & & & 1F Hallway & Hallway & 27.2 & 11 & 1538.09 & 2511.69 & 13.56 & 22.24 & 56.5 & 92.3 & 0.009 & 0.009 & 45 & 0.074 \\
\hline & & Walkway & Exterior Stairs & Stairs & 8.9 & 38 & 926.6 & 1255.88 & 11.17 & 72.77 & 104.1 & 141.1 & 0.012 & 0.058 & 180 & 0.253 \\
\hline & & & 3P Hallway & Hallway & 23.8 & 11 & 2033.8 & 2033.8 & 7.52 & 7.52 & 85.5 & 85.5 & 0.004 & 0.004 & 8 & 0.037 \\
\hline & & & 4F Hallway & Hallway & 41.4 & 6 & 1107.1 & 1107.1 & 22.65 & 22.65 & 26.7 & 26.7 & 0.020 & 0.020 & 31 & 0.017 \\
\hline & & & 3F Lounge & Lounge & 13.2 & 59 & 6355.2 & 7224.78 & 73.61 & 78.31 & 481.5 & 547.3 & 0.012 & 0.011 & 60 & 0.354 \\
\hline & & Room & $4 \mathrm{~F}$ Lounge & Lounge & 13.2 & 91 & 4916.1 & 5406.58 & 63.22 & 76.67 & 372.4 & 409.6 & 0.013 & 0.014 & 28 & 0.368 \\
\hline & & & Bath Room & Bathroom & 10.2 & 6 & 186.7 & 186.7 & 2.57 & 2.57 & 18.3 & 18.3 & 0.014 & 0.014 & 30 & 0.007 \\
\hline
\end{tabular}




\section{CONCLUSION}

This report summarized the procedure and results of a survey that was conducted to obtain knowledge about flammable materials that is vital to assessing a "local fire". In further research, more surveys will be conducted with respect to the use space where a "local fire" can be anticipated and more knowledge will be accumulated with respect to the actual conditions.

\section{REFERENCES}

1. Edited by Japan Association for Fire Science and Engineering, "Fire and Architecture 2.1 Concept of Performance Based Code of Building Standards Law", Kyoritsu Shuppan, pp.11-15, 2002 (in Japanese)

2. Harada K., Ohmiya Y., Takeichi N., Wakamatsu T., Matsuyama K. and Kakae N., "A Proposal for a Set of Databases for use in Fire Resistance Design of Structure against Localized Fires", Summaries of technical papers of Annual Meeting Architectural Institute of Japan. A-2, Fire safety, off-shore engineering and architecture, information systems technology, pp.229-232, 2003 (in Japanese)

3. Kitahori J., Ohmiya Y., Harada K. and Kakae N., "Investigation into the Actual Conditions of Fire Load Location", Summaries of technical papers of Annual Meeting Architectural Institute of Japan. A-2, Fire safety, off-shore engineering and architecture, information systems technology, pp.101-104, 2004 (in Japanese)

4. Working Group of Fire Resistance Design of Structure against Localized Fires, "Symposium of Thinking over Fire Resistance Design of Structure against Localized Fires -Toward Attractive a Fire Resistance Design", Architectural Institute of Japan, 2005 (in Japanese) 